\title{
Consumer's Purchase Intentions towards Automobiles in Pakistan
}

\author{
Abeera Amir*, Muzaffar Asad \\ School of Accounting and Finance, University of Central Punjab, Lahore, Pakistan \\ Email: *beya_amir@hotmail.com
}

How to cite this paper: Amir, A. and Asad, M. (2018) Consumer's Purchase Intentions towards Automobiles in Pakistan. Open Journal of Business and Management, 6, 202-213. https://doi.org/10.4236/ojbm.2018.61014

Received: December 27, 2017

Accepted: January 27, 2018

Published: January 30, 2018

Copyright ( $) 2018$ by authors and Scientific Research Publishing Inc. This work is licensed under the Creative Commons Attribution International License (CC BY 4.0).

http://creativecommons.org/licenses/by/4.0/

\section{(c) (i) Open Access}

\begin{abstract}
The purpose of this paper is to identify and assess the factors which influence the consumer's purchase intentions towards automobiles in Pakistan. After reviewing the literature, the most significant independent variables (price, product, after sale service, brand product quality and brand loyalty) were integrated together into a research framework and then the hypotheses were tested. The unit of analysis was the individual automobiles consumers in Lahore, Pakistan selected as random respondents. The sample size was 250 . Simple regression was used to analyze the results. The findings depicted that the three independent variables-price, product and brand product qualityhave a positive significant relationship with the consumer's purchase intentions towards automobiles while the other two variables i.e. after sale service and brand loyalty showed insignificant results. The managers in the automobile industry as well as the policy makers will find this study helpful, when they will be making strategies (example marketing related) and also while developing auto policy.
\end{abstract}

\section{Keywords}

Purchase Intentions, Price, Product, After Sale Service, Brand Product Quality, Brand Loyalty

\section{Introduction}

In recent years, an exceptional development and progress can be witnessed in the number of passenger cars on the roads all around the world. The advancement of the automobiles has not only made great contributions to the economic development of a country but also considerably changes people's life [1]. Clearly, the automobile industry has entered in the race of innovation and technology. It is repeatedly mentioned by various authors that the automobile industries are 
the key players in contributing to the growth of the GDP in various developed nations. According to the PAMA (Pakistan Automotive Manufacturers Association), the total production of the passenger cars (2017) were 186,936 while the sales figures shown were 185,781 . If we see the production figure of passenger cars in 2016, it depicts the value of 179,944 and the sale figure is 181,145 passengers' cars. Hence, it is evident that the overall the production and also the sale of the cars have been increased from the year 2016 to 2017. These figures only include the passenger cars. There are other categories of automobiles for example trucks, buses, vans and jeeps $(4 \times 4)$ and farm tractors; they have also shown a sharp increase in the sales and production figures (PAMA). Hence, it is evident that overall roads have been flooded with vehicles.

In every country, the automobile industry plays a vital role in the economy. Taking Pakistan, into consideration then based on the facts that Pakistani automobile industry is not much prominent in the world. It is rather expanding in Pakistan from a long time. [2] narrated that there is a hope that the customers are more likely to repurchase the product if they are "satisfied customers" which will expand the market share of the company as well as its overall sales. This shows that company can become profitable if it can satisfy its customers. Satisfaction is a fulfillment of the needs and desires of consumers and thus consumers will repeat purchase Customers when they are satisfied with the experience of the process of purchase or after they consume the goods [3]. Companies providing high quality goods and services might convince the consumers and hence individuals may trust the company to be a profitable investment as well [4]. Before, purchasing the product, the consumers gather the information related to the products and reaches on certain decision and therefore purchase intention is often used to analyze consumer behavior [5].

At present, the Pakistani auto market is dominated by Suzuki, Honda and Toyota. According to various studies, the growth in the economy can be witnessed by the success of the Automobile industry. It also provides job to the millions of people and it may also support other industries. However, in recent years, there has been a change in the preferences of consumers towards the passenger's cars. Consumers choose to purchase an imported cars rather than locally manufactured cars which has affected the local automobile industry of the Pakistan. The import of the automobiles in Pakistan has been escalated as people have shown their keen interest towards the imported cars. Due to different culture, attitude of consumers and moreover the tastes of the consumers vary from one country to another [6]. Currently, people have more choices and alternatives in purchasing the cars than before.

In response to this problem, this study proposes to assess and investigate the important variables that influence the purchase intentions to buy imported cars rather than buying locally manufactured cars among consumers in Pakistan. After investigating the literature, the most significant variables have been selected which are price, product, after sale service, brand product quality and brand 
loyalty [7] [8] [9]. Hence, all these factors will be inculcated in the research article. The paper investigates the relationship of all these factors with the consumer's purchase intentions towards buying the imported cars rather than locally manufactured cars.

\section{Literature Review}

Several researches have been supervised in recent years in both developing and developed countries to analyze and investigate the purchase intentions of automobile consumers. One of the particular aspects of automobile industry is that it constitutes the demand for the raw materials, servicing and distribution leading to a major rippling effect in the economy [10]. Moreover, to assess the purchase intentions of the consumers is very critical as it will help the automobile companies to know about their products worth and behavior of the consumers towards their products. Furthermore, the managers and automobile policy makers will also be benefited. The managers will have better knowledge about the consumer purchase intentions then they can describe the elements which influence behavior of the consumers and also the Policy makers in Pakistan's auto sector would benefit [7].

To best of my knowledge, there is no study yet produced by the various researchers who have accommodated all these variables (product, price, after sale service, product quality and brand loyalty) altogether and have investigates the relationship of all these factors with the purchase intentions of the consumers in Pakistan. Henceforth, this study is motivated to be one of the first studies of said kind aiming to assess the influence of these factors on purchase intentions.

The purchase intentions of the consumers are related to the consumer's readiness to acquire. Purchase intention is part of the behavioral intentions and henceforth, the behavior of the consumer can possibly be turned into course of certain action [11] [12]. The theory of planned behavior has been assessed and the variables that was investigated were attitude, Environmental Consciousness, Environmental Ethics and Beliefs, Social Impression, Perceived Behavioral Control, Subjective Norm [13]. This study attempts to extend the behavior and intentions model i.e. theory of planned behavior by including the all the five independent variables (price, product, after sale service, brand product quality and brand loyalty) and investigating its combined effect on the intentions and behavior of the consumers. In Pakistan, as it evident that the purchase of the cars has reached at its highest levels so that also explains that behavior of the Pakistani consumers towards the automobiles. The impact of price, brand and store information on consumer's judgment about the product quality and their willingness to buy was assessed [9]. Consumers are influenced by word of mouth communications and make purchase decisions. The study on e-word (electronic-word) of mouth was conducted to examine its influence on the brand image and purchase intentions [14]. On the other hand, [6] analyzed the variables i.e. country of origin and the critical function country of origin and assessed its im- 
pact on the consumers' automobile purchase decisions. The variables used in his study were price, quality requirements of the product, risk and social factors.

Another research investigated the impact of self image congruence, perceived corporate brand origin and corporate-brand credibility on purchase intention [15]. The variables attitude, subjective norms, perceived ease of use and perceived risk were analyzed to identify its impact on purchase intentions [7] [16]. has also identified and assessed the key variables which have significant impact on the purchase intentions to purchase passenger cars among consumers in $\mathrm{Pa}$ kistan. The variables of their study were product, price and after sale service. Consequently, [8] investigated the Aaker's consumer based brand equity model and expanded it. The independent variables used in the study were brand association, brand product quality, brand loyalty and after sale service. Another research inculcated country image, product quality and brand familiarity as independent variables in the study [17]. Brand experience, brand trust and affective commitment influence purchase intentions was another research [18]. Moreover, in another research, the mediating role of product judgments has also been tested before along with the consumer ethnocentrism and animosity as independent variables [19]. Another research investigated the effect of attitude, social pressure, perceived behavior control and perceived self identity on purchase intention [20].

Most of the researchers working on the consumer purchase intentions have performed causal research, where they have seen the impact of key factors on the purchase intentions [7] [14] [19]. In this area of domain; researchers have found contrasting results. [9] marked that there is a negative impact of price on perceived willingness to buy but there is a positive relation between price and perceived quality; moreover, other two variables (brand and store information) showed significant results towards the perceptions of quality and willingness to buy. [6] observed that the factors i.e. quality and social factors have significant relation with purchase intentions. [7] identified that product, price and after sale service have significant impact on the dependent variable (i.e. purchase intentions).

\section{Theoretical Framework}

Preceding literature has produced similar outcomes but some variables need to be further analyzed. In the current study, the purpose is to assess the consumer's purchase intentions especially in terms of buying imported cars instead of locally manufactured cars in Pakistan. The literature has also identifies various factors of the purchase intentions. Some of the factors are price, quality requirements of the product, risk and social factors, self image, perceived corporate brand image and corporate-brand credibility, price and after sale service, brand value and brand loyalty and Word of Mouth communication etc. the proposed research framework was established which was based on the above discussion (Figure 1). The study incorporated five independent variables which are the most 


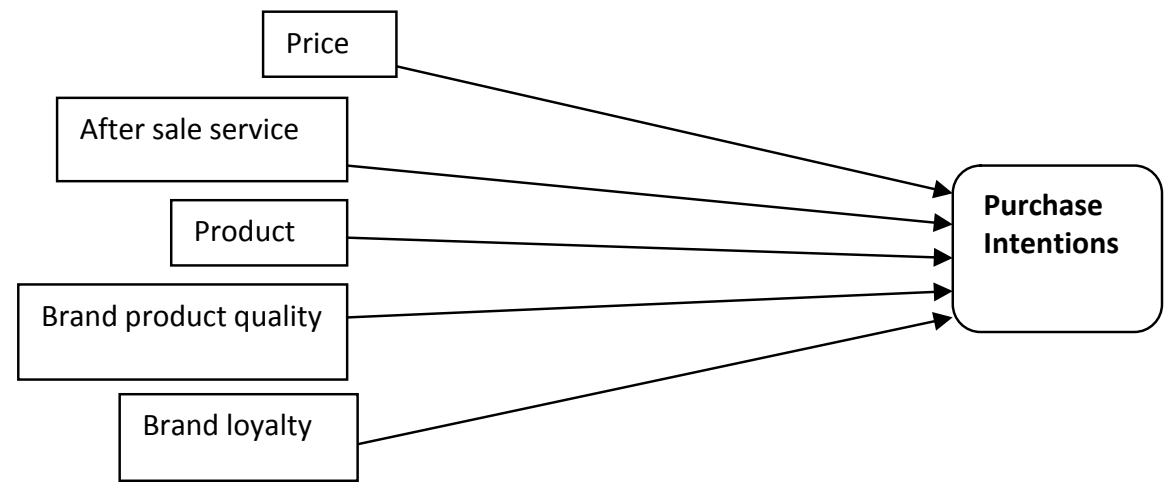

Figure 1. Proposed research framework.

significant, i.e. price, product, after sale service, brand product quality and brand loyalty in finding their relationships with purchase intentions (PI).

Based on the proposed research framework, several hypotheses are tested as follow:

$\mathrm{H1}$ : Price (P) has a significant impact on the purchase intention (PI)

H2: After sale services (AS) has a significant impact on the purchase intention (PI)

H3: Product (PD) has a significant impact on the purchase intention (PI)

H4: Brand product quality (BP) has a significant impact on the purchase intention (PI)

H5: Brand loyalty (BL) has a significant impact on the purchase intention (PI)

\section{Methodology}

The collection of the data for the purpose of the survey has been done through questionnaire. Table 1 shows the items along with its sources. The five point likert scales ranging from strongly disagree to strongly was used in all the items. The unit of analysis of the study was the individual consumers of automobiles in Lahore, Pakistan. The respondents were both male and female between the age group of 29 to 50 years old. A total of 326 responses were gathered out of which 76 responses were neglected because of incomplete questionnaires, thus leaving 250 responses. Hence the overall response rate was $76 \%$.

The data was then analyzed on the SPSS software to run the regression for the purpose of finding the impact of predictors on the response variable. The equation formed on the basis of the proposed framework is :-

$$
\begin{aligned}
Y= & \beta_{o}+\beta_{1} \text { price }+\beta_{2} \text { after sale service }+\beta_{3} \text { product } \\
& +\beta_{4} \text { brand product quality }+\beta_{5} \text { brand loyalty }
\end{aligned}
$$

where, $Y=$ refers to purchase intentions

\section{Results and Analysis}

Table 2 depicts the values of the $\mathrm{R}$ along with the values of $\mathrm{R}$ square, standard error of the Estimate and Durbin-Watson. The coefficient of determination 
Table 1. Questionnaire source and number of items.

\begin{tabular}{ccl}
\hline Constructs & Items & \multicolumn{1}{c}{ Source } \\
\hline Purchase intentions & 7 & $\begin{array}{l}\text { Theo et al. (2008) and Ekam (2013) } \\
\text { Yoo, et al. (2000), Ahmad and Butt (2012) and } \\
\text { Al-Dmour et al. (2013) } \\
\text { After sale service }\end{array}$ \\
Yoo, et al. (2000), Ahmad and Butt (2012) and \\
Al-Dmour et al. (2013) \\
Product & 7 & $\begin{array}{l}\text { Raoof (1997) } \\
\text { Sajjad Ahmad and Muhammad Mohsin Butt, (2012) }\end{array}$ \\
Brand loyalty & 12 & Sajjad Ahmad and Muhammad Mohsin Butt, (2012) \\
\hline
\end{tabular}

Table 2. Model summary.

\begin{tabular}{|c|c|c|c|c|c|c|c|c|c|c|}
\hline \multirow[b]{2}{*}{ Model } & \multirow[b]{2}{*}{$\mathrm{R}$} & \multirow{2}{*}{$\begin{array}{c}\mathrm{R} \\
\text { Square }\end{array}$} & \multirow{2}{*}{$\begin{array}{l}\text { Adjusted } \\
\text { R Square }\end{array}$} & \multirow{2}{*}{$\begin{array}{l}\text { Std. Error } \\
\text { of the } \\
\text { Estimate }\end{array}$} & \multicolumn{5}{|c|}{ Change Statistics } & \multirow{2}{*}{$\begin{array}{l}\text { Durbin } \\
\text { Watson }\end{array}$} \\
\hline & & & & & $\begin{array}{l}\text { R Square } \\
\text { Change }\end{array}$ & $\begin{array}{c}\mathrm{F} \\
\text { Change }\end{array}$ & $\mathrm{df1}$ & $\mathrm{df} 2$ & $\begin{array}{c}\text { Sig. F } \\
\text { Change }\end{array}$ & \\
\hline 1 & $0.872^{\mathrm{a}}$ & 0.761 & 0.756 & 0.20375 & 0.761 & 155.377 & 5 & 244 & 0.000 & 1.799 \\
\hline
\end{tabular}

is the "R Square" which has a value of 0.76 . The predictors brand loyalty, after sale service, product, product quality and price are explaining the $76 \%$ variation in purchase intentions. The value of 1.799 of Durbin-Watson shows that the possibility of autocorrelation is minimal.

To examine the combined effect of Predictors on the dependent variable, the analysis of variance test is used [21]. Table 3 is the ANOVA model which comprises of the variance analysis between after sale service, price, product, brand loyalty, product quality and purchase intentions. As the significance value is 0.00 , it means that the model is a good fit overall.

The coefficients are displayed in Table 4. This table is showing the significant and insignificant values of the independent variables. The independent variables price, product and product quality have significance value less than $0.05 \mathrm{ex}-$ plaining that these hypotheses are accepted. While the independent variables after sale service and brand loyalty values are greater than 0.05 , demonstrating that these hypotheses are rejected.

Table 5 summarizes the results of the study. The H1 is accepted meaning that price has a positive significant impact on purchase intentions. In majority of the studies, the variable price has a positive significant relation with the purchase intentions. The $\mathrm{H} 2$ after sale service has been rejected because its p-value is greater than 0.05 . Similarly, the H5 (brand loyalty) is also rejected because its p-value is 0.54 which is greater than 0.05 . This indicated that after sale services and brand loyalty doesn't influence the consumer's purchase intentions. Moreover, the $\mathrm{H} 3$ and $\mathrm{H} 4$ are important factors which influence the purchase intentions. Consumers are concerned about the product itself and the brand product quality in making purchase decisions. 
Table 3. ANOVA Table.

\begin{tabular}{ccccccc}
\hline \multicolumn{1}{c}{ Model } & Sum of Squares & df & Mean Square & F & Sig. \\
\hline & Regression & 32.253 & 5 & 6.451 & 155.377 & $0.000^{\mathrm{b}}$ \\
1 & Residual & 10.130 & 244 & 0.042 & & \\
& Total & 42.382 & 249 & & & \\
\hline
\end{tabular}

Table 4. Coefficients.

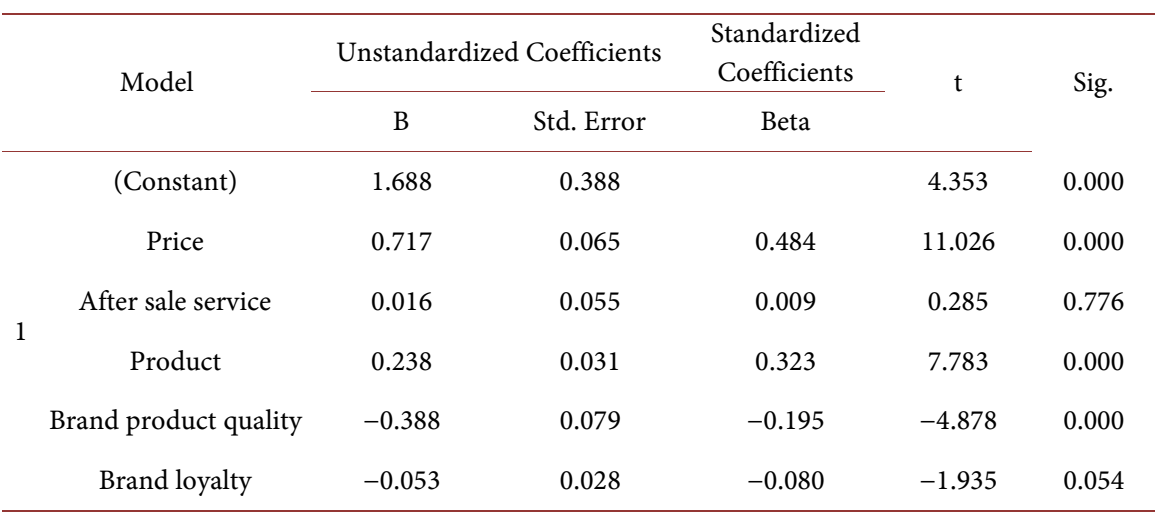

Table 5. Summary of the results.

\begin{tabular}{ccc} 
Hypothesis & p-value & Decision \\
\hline H1: Price (P) and purchase intention (PI) & 0.000 & Accepted \\
H2: After sale services (AS) and purchase intention (PI) & 0.776 & Rejected \\
H3: Product (PD) and purchase intention (PI) & 0.000 & Accepted \\
H4: Brand product quality (BP) and purchase intention (PI) & 0.000 & Accepted \\
H5: Brand loyalty (BL) and purchase intention (PI) & 0.054 & Rejected \\
\hline
\end{tabular}

\section{Conclusions}

The major purpose of this study is to investigate the consumer's purchase intentions towards automobiles in Pakistan. It is crucial to have an understanding of the purchase intentions and decisions of the consumers because it is an intermediary to actual consumption. The results of the study have revealed interesting findings. The three independent variables-price, product and brand product quality-have a positive significant relationship with the consumer's purchase intentions towards automobiles. While the other two independent variables-after sale service and brand loyalty-revealed an insignificant relationship with consumer's purchase intentions.

The results of the study indicated that the consumers believed that the prices of the locally manufactured cars are high. Therefore, instead of buying high priced locally manufactured cars, they prefer to purchase imported cars. Hence, price is an important factor in assessing the purchase intentions of the buyers. Another research finding indicated that there is a statistical significant relationship among the product and purchase intentions and the result showed that the 
locally manufactured cars lack the technological advancements and creativity. So as a product, imported cars are preferred by the consumers as compare to local cars. The last significant variable was the brand product quality. One of the most important feature on which almost all the respondents agreed was on brand product quality. They agreed that imported cars are of good, reliable and of consistent quality as compare to locally manufactured cars. The other two independent variables after sale service and brand loyalty showed insignificant results. These finding depicted that consumers preferred element of brand product quality and price while making a purchase of automobiles rather than being brand loyal. Due to the intense competition, many automobile companies introduce new models of cars almost every year or maximum after one year. Moreover, the companies also have the knowledge that the preference of the consumers does change with the passage of the time.

In the automobile sector of Pakistan, various practitioners may find this research helpful in determining the preferences of the consumers. When making the strategies related to marketing, the most crucial task is to look for the factors that influence the needs of the consumers [22]. The managers in the automobile industry can upgrade their marketing strategies for upcoming products, and even for the existing products. This study can also help the policy makers while developing the Auto Policy.

\section{Future Research}

The study has identified the factors that influence purchase intentions of the consumers towards automobiles in Pakistan. The research in this study was narrowed to only five most significant variables (price, after sale service, product, brand product quality and brand loyalty) from the previous studies. Future research can be conducted on variables like economics, social influences and status, culture and relationship with the car dealers and a new framework can be constructed. Moreover, the researchers can conduct the study on moderating role of personality and culture in the proposed framework. Another future research can be conducted by adding the mediating variable subjective norm from Ajzen's Theory of Planned Behavior in the proposed research framework.

\section{References}

[1] Chang, W.J., Liao, S.H. and Wu, T.-T. (2017) Relationships among Organizational Culture, Knowledge Sharing, and Innovation Capability: A Case of the Automobile Industry in Taiwan. Knowledge Mangagement Research \& Practice, 15, 471-490. https://doi.org/10.1057/s41275-016-0042-6

[2] Innis, D.E. and Londe, B.J.L. (1994) Modelling the Effects of Customer Service Performance on Purchase Intentions in the Channel. Journal of Marketing Theory and Practice, 2, 45-60. https://doi.org/10.1080/10696679.1994.11501650

[3] Gunawan, S. and Supit, V.H. (2014) The Influence of Store Atmosphere on Emotional Responses and Re-Purchase Intentions. Business Management and Strategy, 5, 151-164. https://doi.org/10.5296/bms.v5i2.6144

[4] Hoffmann, A.O.I. and Ketteler, D. (2015) How Experiences with Trading a Com- 
pany's Stock Influence Customer Attitudes and Purchasing Behavior. International Journal of Bank Marketing, 33, 963-992.

https://doi.org/10.1108/IJBM-11-2014-0163

[5] Bhakar, D.S.S., Bhakar, S. and Bhakar, S. (2013) Relationship between Country of Origin, Brand Image and Customer Purchase Intetnions. Far East Journal of Psychology and Business, 10, 25-47.

[6] Sadiq, S.M. and Gokhan, S.O. (2010) Country-of-Origin Effects on Consumers' Evaluations of Automobiles: Perspectives from a Developing Nation. Journal of International Consumer Marketing, 22, 245-257. https://doi.org/10.1080/08961531003751058

[7] Altaf, S.N. and Hashmi, N. (2016) Key Factors Influencing Purchase Intentions towards Automobiles in Pakistan. Paradigms: A Research Journal of Commerce, Economics, and Social Sciences, 10, 14-22.

[8] Sajjad, A. and Butt, M.M. (2012) Can after Sale Service Generate Brand Equity? Journal of Marketing Intelligence \& Planning, 30, 307-323. https://doi.org/10.1108/02634501211226285

[9] Dodds, W.B., Grewal, D. and Monroe, K.B. (1991) Effects of Price, Brand, and Store Information on Buyers' Product Evaluations. Journal of Marketing Research, 28, 307-319. https://doi.org/10.2307/3172866

[10] Veena and Venkatesha (2008) Dealers Performance and Customers Preference in Passenger Car Marketing. Vilakshan: The XIMB Journal of Management, 5, 59-70.

[11] Ajzen, I. and Fishbein, M. (1980) Understanding Attitudes and Predicting Social Behaviour.

[12] Ajzen, I. (1985) From Intentions to Actions: A Theory of Planned Behavior. Action Control, 11-39.

[13] Chen, S.C. and Hung, C.W. (2016) Elucidating the Factors Influencing the Acceptance of Green Products: An Extension of Theory of Planned Behavior. Technological Forecasting and Social Change, 155-163. https://doi.org/10.1016/j.techfore.2016.08.022

[14] Jalilvand, M.R. and Samiei, N. (2012) The Effect of Electronic Word of Mouth on Brand Image and Purchase Intention: An Empirical Study in the Automobile Industry in Iran. Marketing Intelligence \& Planning, 30, 460-476.

https://doi.org/10.1108/02634501211231946

[15] Li, Y., Wang, X. and Yang, Z. (2011) The Effects of Corporate-Brand Credibility, Perceived Corporate-Brand Origin, and Self-Image Congruence on Purchase Intention: Evidence from China's Auto Industry. Journal of Global Marketing, 24, 58-68. https://doi.org/10.1080/08911762.2011.545720

[16] Posakabutra, W. (2015) Consumer's Purchasing Intention of Luxury Women's Handbags: Comparative Study of Online and In-Store Purchase in Bangkok. Business Sciences International Research Journal, 3, 22-28.

[17] Yunusa, N.S.N.M. and Rashidb, W.E.W. (2016) The Influence of Country-of-Origin on Consumer Purchase Intention: The Mobile Phones Brand from China. Procedia Economics and Finance, 37, 343-349. https://doi.org/10.1016/S2212-5671(16)30135-6

[18] Yasin, M. and Shamim, A. (2013) Brand Love: Mediating Role in Purchase Intentions and Word-of Mouth. Journal of Business and Management, 7, 101-109. https://doi.org/10.9790/487X-072101109

[19] Ferrín, P.F., Vilela, B.B., Klein, J.G. and Araújo, M.L.R. (2015) Consumer Ethno- 
centrism and Consumer Animosity: Antecedents and Consequences. International Journal of Emerging Markets, 10, 73-88.

https://doi.org/10.1108/IJOEM-11-2011-0102

[20] Tan, T.H. (2013) Use of Structural Equation Modeling to Predict the Intention to Purchase Green and Sustainable Homes in Malaysia. Asian Social Science, 9, 181. https://doi.org/10.5539/ass.v9n10p181

[21] Abid, R. and Khattak, A. (2017) Brand Avoidance Motivators Stimulate to Brand Equity in the Mediating Role of Brand Hate: A Case of Smartphone Industry of Pakistan. Journal of Accounting and Marketing, 6, 250.

[22] Narteh, B., Odoom, R., Braimah, M. and Buame, S. (2012) Key Drivers of Automobile Brand Choice in Sub-Saharan Africa: The Case of Ghana. Journal of Product and Brand Management, 21, 516-528. 


\section{Questionnaire}

$\begin{array}{llllll}\text { Purchase Intentions } & \begin{array}{c}\text { Strongly } \\ \text { Disagree }\end{array} & \text { Disagree } & \text { Neutral } & \text { Agree } & \begin{array}{c}\text { Strongly } \\ \text { Agree }\end{array}\end{array}$

In purchasing cars, I will purchase a locally assembled one

In purchasing cars, I will not purchase a locally assembled one

I will only purchase imported cars when locally assembled cars are not available.

I will recommend purchasing locally assembled cars to my friends.

I will purchase locally assembled cars even at higher prices.

I would consider purchasing a locally assembled car.

There is a good probability that I would consider purchasing locally assembled car.

\begin{tabular}{|c|c|c|c|c|c|}
\hline Price & $\begin{array}{l}\text { Strongly } \\
\text { Disagree }\end{array}$ & Disagree & Neutral & Agree & $\begin{array}{c}\text { Strongly } \\
\text { Agree }\end{array}$ \\
\hline
\end{tabular}

The price of locally assembled cars is high

The price of locally assembled cars is low

Locally assembled cars are expensive

Locally assembled cars are inexpensive

Overall, I think a locally assembled car will be good value for the money

If I buy a locally assembled car, I will be getting my money's worth.

If I buy a locally assembled car, I will be getting a good car for a reasonable price.

\begin{tabular}{|c|c|}
\hline After Sales Services & $\begin{array}{l}\text { Strongl } \\
\text { Disagre }\end{array}$ \\
\hline
\end{tabular}

Spare parts of locally assembled cars are easily available

Spare parts of locally assembled cars are low priced

Technical support for locally assembled cars is easily available

Technical support for locally assembled cars is low priced

Warranty on new locally assembled cars is an important feature for me

In general, repair and maintenance services provided for locally assembled cars are adequate

\begin{tabular}{|c|c|c|c|c|c|}
\hline Product & $\begin{array}{l}\text { Strongly } \\
\text { Disagree }\end{array}$ & Disagree & Neutral & Agree & $\begin{array}{c}\text { Strongly } \\
\text { Agree }\end{array}$ \\
\hline
\end{tabular}

Locally assembled cars are suitable for the local Pakistani market

Locally assembled cars have made improvements to their suitability for Pakistani driving conditions

Locally assembled cars are competitive

Locally assembled cars have acceptable workmanship

Locally assembled cars are of acceptable quality

Locally assembled cars are technologically advanced

There is creativity in locally assembled cars

Locally assembled cars are imitations of foreign cars

There is variety in locally assembled cars

Locally assembled cars have good appearance 


\section{Continued}

Locally assembled cars come in different colors and designs

Locally assembled cars are reliable

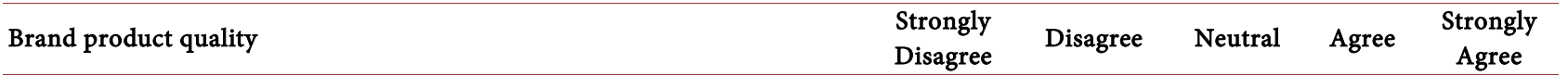

Imported cars are of good quality

Imported cars are of consistent quality

Imported cars are very durable

Imported cars are very reliable

Imported cars have excellent features

\begin{tabular}{|c|c|c|c|c|c|}
\hline Brand Loyalty & $\begin{array}{l}\text { Strongly } \\
\text { Disagree }\end{array}$ & Disagree & Neutral & Agree & $\begin{array}{c}\text { Strongly } \\
\text { Agree }\end{array}$ \\
\hline
\end{tabular}

I feel loyal to imported brand car company

Imported cars are my first choice

I would love to recommend imported car brands to my friends

I am willing to buy imported car brand even if price is a little higher than other similar locally manufactured car 